\section{A LOOK BACK}

\section{THE Voyage OF \\ Captain Don Felipe González in the ShIP OF THE LINE SAN LORENZO, WITH THE FRIGATE SANTA ROSALIA IN COMPANY, TO EASTER ISLAND IN 1770-1}

Transcribed, Translated, and Edited by Bolton Glanvill Corney from the official MS. records preserved in the General Collection of the Archives of the Indies, at Sevilla, the Hydrographic Office of the Ministry of the Navy, and the library of the Royal Academy of History, at Madrid.

The Hakluyt Society, Cambridge, 1908.

DESPATCH No. 396 from the viceroy of Peru, to The Secretary of State for the Indies.

Most Excellent Señor,

In my dispatch No 363 , of the $10^{\text {th }}$ of October 1770,1 acquainted Your Excellency with the arrangements to which effect was on that date given, in obedience to a Royal command of the $26^{\text {th }}$ of October 1769 , by the sailing of the ship of war $S^{n}$ Lorenzo and H.M. frigate the $S^{\text {ta }}$ Rosalia ${ }^{1}$ from the port The Callao, to search for the island of David, and to examine others in the South Sea and off the coasts of Chiloe whereat the English might have established themselves. My communication was accompanied by copies of the instructions and documents with which I furnished the commanding officers for their guidance during the commission. Being attended by good fortune that they on the $15^{\text {th }}$ of November sighted the island in question, which differs only slightly in its position from that generally laid down on the charts. A party being soon landed, they explored some portion of the interior, and also rowed round it, examining its harbours, coves, and bays, and taking bearings for a running survey. They took possession of it in the name of his Majesty, whose Royal appellation was bestowed upon it, in conformity with the instructions.

The information gained as to its inhabitants, their character, ceremonies, customs, and religion, is somewhat: restricted by reason of the language being strange to our people, and in consequence of their stay being limited to a few days only. The accounts merely state that islanders appear to be mild in bearing, and well disposed towards visitors, before whom they behaved with great good-will. Neither from their hue nor from their features was it possible to arrive at any definite conclusion as what race their origin is traceable from and it seems merely that they lead a simple existence very similar to that which prevailed in the most primitive states of the world, possessing their goods, and the fruits they cultivate, in common. The soil, which is fer- tile enough, is suitable for this and provides them with such necessaries of life as might be expected to flourish in the latitude of $27^{\circ} 15^{\prime}$ and longitude $264^{\circ} 36^{\prime}$ according to the observation taken the $16^{\text {th }}$ of November. Nor is it possible to form an exact opinion of the number of the inhabitants, nor whether. they recognise any chief authority, nor as to other matter connected with their history our people not having penetrated to the inner recesses of the island, being apparently impressed with the importance of using despatch, to the end that the commission might be brought to a close in proper season. In pursuance of this design the two vessels left the island on the 21st of the said month of November, shaping a course for the harbour of $\mathrm{S}^{\mathrm{n}}$ Carlos in the Province of Chiloe, with the object of procuring coastal pilots for continuing their visit to that coast as far as the prescribed limit to the southward. On arrival there, however, they learned the situation of matters in connection with the reconnoitering of those coasts as carried out by the then Governor, $\mathrm{D}^{\mathrm{n}}$ Carlos Berenguer, acting under instructions from me and they therefore changed their plans and destination, in accordance with a resolution agreed upon by a general Council of War which they held for the purpose. Taking advantage of the sailing of a small schooner for the port of La Concepcion in Chile, the officer commanding the $S^{n}$ Lorenzo, Don Felipe Gonzalez, forwarded on to me the log, charts, and documents referred to in the letter of the 3rd of January, of which I enclose a copy, together with the affidavits and papers to which it has reference. It is from these, and others which came to hand by the same opportunity, that the information which I have put together in the form of a summary regarding the island has been taken. I received by the same vessel a despatch from the before mentioned Governor Berenguer, accompanied by the log drawn up by $\mathrm{D}^{\mathrm{n}}$ Josef Ruis of his examination of the archipelago and harbours of the coast of Chiloe, of which also I enclose a copy.

By the measures thus taken not only is the nonexistence of any English in those parts placed beyond a doubt, but the iron-bound nature of the coast has been shown to be such as to afford no inducement to strangers to occupy it. Lastly, the noted harbour of Inche or Inchin has no other settlement than that I mentioned in the 18th paragraph of the Instructions sent with my dispatch of the 10th of October so that I only await now any information which the said two vessels may furnish on their return with regard to new lands or islands in the intervening tract, which it is suspected the English may have selected in preference - if they have gained a footing anywhere at all - by reason of the milder climate one may suppose to prevail in about $30^{\circ}$ of latitude $\mathrm{S}$.

From this it follows that such measures as may appear most suitable should be taken for protecting these coasts against aggression from so strategic a vantage point since, computing the course from this port of The Callao to the

\footnotetext{
' Under the command of Don Felipe Gonzalez y Haedo, a Captain in the Royal Navy of Spain, instructed by the Viceroy of Peru in obedience to the King's Orders.
} 
island of $S^{n}$ Carlos, or David, at a little more or less than twenty days' sail for difference of longitude, and six or seven days' for southing, we should find ourselves exposed to a constant menace ${ }^{5}$ if once a foreign enemy of whatsoever nation should gain effective possession, and establish themselves there, where they would have the advantage of meeting with a native race upon the spot, who, when civilised, could supply the places of any Europeans who might be lacking. For these reasons I consider it imperative that we should forestall them by taking possession and effectively occupying the island, either by fortifying it, or by removing the native population to this country and forming them into colonies or village settlements, as might be determined by statute.

On account of all of which it is my desire that Your Excellency may acquaint me with whatever decision shall prove most in conformity with His Majesty's pleasure in this matter, in order that I may render satisfaction, and merit that approval to which I aspire.

May Our Lord preserve to Your Excellency many years of life. Lima, the $5^{\text {th }}$ of February, 1771. Most Excellent Señor, Your Excellency's most faithful servant kisses your hand.

\section{MANUEl DE AMAT}

To the Most Excellent Señor, Brother Don Julian de Arriaga, Knight of Justice of the Order of St John of Malta. ENCLOSURES: Despatch from Don Felipe González, commanding the ship of war $S^{n}$ Lorenzo, and documents accompanying the same. [Enclosure to Despatch $n^{\circ}$ 396.]

\section{Report of Arrival at SAN Carlos de ChILOE}

[FROM CAPTAIN D ${ }^{N}$ FELIPE GONZALEZ, TO D ${ }^{N}$ JULIAN DE ARRIAGA, SECRETARY OF STATE FOR THE INDIES.]

Most Excellent Señor, - I take the opportunity afforded by the sailing of a trading schooner for the port of La Concepción in Chile of being able to advise Your Excellency of the occurrences during my commission to this date, which period has been productive of the happy result that I have met with the island commonly called David's, although it is badly placed on the French and Dutch charts. I have examined its entire outline with the ship's boats, and explored the interior with an armed party who got as far as its centre; and have prepared a plan after both methods, which I am forwarding to Your Excellency with the log, and [the report of proceedings of] two Councils of War which I deemed it necessary to hold, for the reasons expressed therein.

In furtherance of which I came into port, and continued here awaiting such [intelligence] as might be brought in by two piraguas dispatched by the Governor to examine Inchin as far as the point of Tres Montes. These having arrived on the $30^{\text {th }}$ of this [month] with information to the effect that there is no harbour there, nor any foreign settlement whatsoever, nor any place thereabouts or in the neighbourhood where one could possibly be formed; and there being nothing left for me to do down there, according to the report given by the commander of the piraguas, I am only awaiting an opportunity to put to sea and to follow the parallel of $29^{\circ}$ to $30^{\circ}$ of latitude as far as $260^{\circ}$ longitude, where, in passing, I saw signs of land and I am persuaded that, being so, it may be some of the islands discovered by $\mathrm{Mr}$ Bryon; and from thence to make for the poor of The Callao and finish my commission.

In reference to these matters I have steadily directed my attention to following the instructions with which I set out on the voyage; nevertheless it became expedient for me to diverge from my course by reason of the considerations stated at the Councils, and bearing in mind that I must use all due discretion and prudence in the event of any difficulty arising, I deemed it proper to abide by the decision of my officers and pilots; it appearing to me that their assistance will be the most proper and suitable in its results for His Majesty's Service, and will consequently prove acceptable to Your Excellency, whose approval it is my desire to merit.

May Our Lord preserve the life of Your Excellency for many years, as is my desire and need: On board the $S n$ Lorenzo, at anchor in the harbour of $\mathrm{S}^{\mathrm{n}}$ Carlos of Chiloe, January 3, of 1771 .

Most Excellent Señor, I kiss Your Excellency's Hand,

PHELIPE GONAZALEZ

To the Most Excellent Señor Brother $\mathrm{D}^{\mathrm{n}}$ Julian de Arriaga, Knight of Justice of the Order of St John of Malta

[Documents accompanying the foregoing.]

EXTRACT from the LOG kept by Captain $\mathrm{D}^{\mathrm{n}}$ Felipe Gonzalez de Haedo, commanding H.M. ship of the line named " $S$ "Lorenzo," which, in accordance with Royal Warrants issued by The Most Excellent Señor Du Manuel de Amat y Junient, Knight of the Order of St John, Member of H.M. Council, Gentleman of the Bedchamber, Lieutenant General of the Royal Army, Viceroy, Governor, and Captain General of the Kingdoms and Provinces of Peru and Chile, sailed from the Port of The Callao of Lima, with the Frigate " $S^{t a}$ Rosalia" in company, commanded by Captain D ${ }^{\mathrm{n}}$ Antonio Domonte each vessel being provisioned for six months.

On the 10th of October 1770, Thursday, at three in the afternoon, we made sail with the wind at S. with fine weather, heading W. At nine at night the N.W. point of the island of San Lorenzo del Callao was visible bearing E. $1 / 4$ S.E., distant two leagues, and I took my departure from that position, which is $11^{\circ} 58^{\prime}$ lat. S. and $298^{\circ} 24^{\prime}$ long. from the meridian of Tenerife.

From thence until the $15^{\text {th }}$ of the same the weather was fine, and wind varied between S. and S.S.E., and at noon I got an observation of the sun in $17^{\circ} 22^{\prime}$ lat. and considered my longitude to be $291^{\circ} 15^{\prime}$.

From noon on the $15^{\text {th }}$ of October until the $19^{\text {th }}$ the same hour the winds were very variable from E. to S.E., fine, and of unequal strength at noon on this day I observed the sun in $20^{\circ} 57^{\prime}$ lat. S., and considered myself to be in long. $288^{\circ} 24^{\prime}$. 


\section{Corney: The Voyage of Captain Don Felipe Gonzalez}

From noon on the $19^{\text {th }}$ of October to the $24^{\text {th }}$ at the said hour the winds were from S.E. to E.N.E. very fitful and puffy with occasional light squalls, the sea lumpy, the horizon obscured. At noon on this day I observed the sun in $26^{\circ}$ $54^{\prime}$ lat. S. and considered myself to be in long. $284^{\circ}$.

From noon on the $24^{\text {th }}$ of October we steered W. $1 / 4$ S.W. westerly, so that my course when corrected amounted to trifle south of W. The wind is E.N.E. moderate, with smooth sea all our canvas is set. From this day until the $31^{\text {st }}$ of the same [month] the winds have been very variable from $\mathrm{W}$. to E.S.E. and unequal in force, with gusts and light squalls, and a good deal of sea from the S.W. and S.E. At noon on this day I observed the sun $27^{\circ} 16^{\prime}$ lat. S., and considered myself in long. $279^{\circ} 52^{\prime}$.

From the 1st of November we steered W. $5^{\circ} \mathrm{S}$. in order to make a course W. corrected the wind was at E.S.E. moderate, the sea smooth, and we had all sail set.

From this day until the $3^{\text {rd }}$ of the said [month] the winds were from the S.E. and S.S.E., fine. On this day I observed the sun in $27^{\circ} 9^{\prime}$ lat. S., and I considered myself in long. $277^{\circ} 37^{\prime}$

From the $3^{\text {rd }}$ of November at noon until the $8^{\text {th }}$ at the same hour the winds were from S.S.E., S.E., and E.S.E., variable, light, and unequal in force, and the sea smooth. At noon this day I observed the sun in $27^{\circ} 14^{\prime}$ lat., and considered myself in long. $272^{\circ} 18^{\prime}$ and the night having set in with the horizon obscure, I lay to all night with the mainyard aback until five o'clock in the morning when, after taking a good look round, I made all sail.

From noon on the $8^{\text {th }}$ of November until the $9^{\text {th }}$ at the same hour the wind was light to moderate from E.N.E., the sea smooth, and the horizon clear. I steered W., a trifle southerly, to make a W. course, corrected, with all sail set; and at sunset I shortened sail so as to cover six or eight leagues, and kept a good look out, so as not to overrun my distance. At midnight I laid the yards aback and so remained until 5 o'clock in the morning, when after taking a good look round I made all sail on a course W. $1 / 4 \mathrm{~S}$.W. At noon I observed the sun in $27^{\circ} 21^{\prime}$ lat. S. and considered myself in long. $270^{\circ} 40^{\prime}$.

From the $9^{\text {th }}$ to noon on the $10^{\text {th }}$ of the said [month] the wind was fresh from N.E., N., and N.N.W., the sea smooth, and the horizon cloudy. I steered W. a trifle southerly, to make a West course, corrected from 9 o'clock at night I remained with the yards aback until dawn, when, after taking a good look round, I continued my course under all sail. At noon I observed the sun in $27^{\circ} 27^{\prime}$ lat. S., and considered myself in long. $269^{\circ} 10^{\prime}$.

From the $10^{\text {th }}$ until noon on the $11^{\text {th }}$ of the said [month] I steered S.W. $1 / 4$ W. with the wind at N.W., fine, dying away at 4 in the afternoon to a calm. At midnight it came away from the S.E. with squalls, and I resumed my course to the W. $1 / 4 \mathrm{~N}$.W. At noon this day I observed the sun in $27^{\circ} 23^{\prime} \mathrm{S}$., and considered myself in long. $267^{\circ} 53^{\prime}$.

From the $11^{\text {th }}$ of the said [month] to noon of the $12^{\text {th }}$ the breeze continued fresh from the S.E., E.S.E., and E., the

\footnotetext{
${ }^{2} \mathrm{~A}$ compass point is missing here.
}

sea short and lumpy, coming from the direction of the wind and from the S.W., and clouds gathered above the horizon. I steered W. $1 / 4 \mathrm{~N}$.W. in order to gain the 27 th parallel. At six in the evening I stood away a bit to the S.W., to reconnoitre a loom which appeared to me like land, which however melted away at sundown and I hove to with the main topsail aback until dawn, after which, having taken a good look round, I steered W. under all plain sail. At noon I observed the sun in $27^{\circ}$ lat. S., and considered myself in long. $266^{\circ}$ $45^{\prime}$.

From the $12^{\text {th }}$ until noon of the 13th of the said [month] I steered W. $5^{\circ} \mathrm{S}$, , to make a West course, corrected; the wind being at E.S.E., fine, with a clear horizon. At nightfall I lay to until dawn, when, after taking a good look round, I made all sail W.1/4S.W. a trifle westerly. At noon this day I observed the sun in $27^{\circ}$ lat. S., and considered myself in long. $265^{\circ} 59$.

From the $13^{\text {th }}$ until noon of the $14^{\text {th }}$ of the said [month] I steered W. $5^{\circ} \mathrm{S}$., with the wind at E. almost calm, the horizon clear, and sea smooth. At two o'clock in the afternoon it became a dead calm, and so remained until four in the morning, when a breeze sprang up from N.W. $1 / 4 \mathrm{~N}$., and keeping a good lookout, I stood to the W.1/4S.W.

At half-past seven in the morning I laid my yards aback and made the signal for the Commander, and officers of the frigate, First Pilot, and Coastal Pilot, to come on board here at ten o'clock. On their arrival I held a Council of War. At noon this day I observed the sun in $27^{\circ} 14^{\prime}$ lat. S., and considered myself in long. $265^{\circ} 38^{\prime}$.

From the $14^{\text {th }}$ until noon of the $15^{\text {th }}$ of the said [month] I steered S.W. $5^{\circ}$ W. with the wind N.W., fine. At six in the evening I looked out ahead and the appearances led me to furl my sails, remaining hove to under the main course until dawn, when, after scanning the horizon I got under way with a S.E. breeze, steering N.W. At seven in the morning I got sight of an island to which I gave the name of San Carlos, its most northerly part bearing N.W. distant 8 or 10 leagues. At eight in the morning I steered W.N.W. in order to come up with the south end of it. At noon this day I observed the sun in $27^{\circ} 15^{\prime}$ lat. S., and considered myself in long. $264^{\circ} 36^{\prime}$; and at the same time I had in view the N.E. point of the island of San Carlos bearing N., the S.W. point bearing W.N.W., $61 / 2^{2}$ and the middle part of it bearing N.W. N. $3^{\circ}$ N., distant at the nearest part four leagues.

From the $15^{\text {th }}$ until noon of the $16^{\text {th }}$ of the said [month] I continued sailing W.N.W., with the wind at S.E.; and finding that the swell was setting me towards the island, I altered the course to N.N.E. and ordered a good lookout to be kept at the mastheads and on the yards; intending to gain a sheltered position on the north side of the island. Having rounded [the N.E. point] at a distance of a mile and a half off I saw that there was a bay to the westward of it, so I ordered the boat to be lowered, and made a signal to the frigate to do the same, and as soon as the boat was in the water I gave orders to Lieutenant Don Alberto Olaondo and to the First Coastal Pilot Ensign Don Juan Hervé to proceed 
in her to take soundings in the bay, taking along with them some marines under arms. At four in the afternoon I took a cast of the lead, being one and a half leagues distant from the land, and got no bottom at 120 fathoms. At half-past four I made a board inshore in order to watch for the boat's signal, to see whether I could anchor. At six I stood out again and kept her lulling into the wind to pick up the boat, which on her arrival, I hoisted in. She brought me information that they had found bottom at 35 fathoms, coarse sand, with some gravel, a mile and a half off the land. At sundown I took bearings of the N.E. point at E.S.E. $8^{\circ} \mathrm{S}$., the W. point N.W. $5^{\circ}$ N., and two hilltops which are opposite the centre of the bay at S. $5^{\circ} \mathrm{W}$., magnetic, distance from the said centre of the bay two and a half leagues. During the night I stood off and on under the courses only, and at halfpast four in the morning I ordered the pinnace and jolly boat to be lowered, the former being sent in to the anchorage to guide me to it. When she got there I followed in after her and at eight o'clock I let go the port anchor in 30 fathoms, sand and gravel, furled all the sails, and at nine ran out a stream cable to the W.N.W., distant a good mile from the land.

On Wednesday the 21st November 1770 , at two in the afternoon, I got under way and quitted the island of San Carlos, vulgarly called David's, heading W., with a light breeze at E.S.E., in order to place myself in $260^{\circ} 20^{\prime}$, which is the longitude in which the Dutch chart lays down another island with the same name of David, in order to be assured as to whether there are two, or one only.

At noon on the $23^{\text {rd }}$ of the same I observed the sun in $27^{\circ} 9^{\prime}$ lat., and considered myself in long. $260^{\circ} 51^{\prime}$; and seeing that we had no indications of there being land near, such as birds, floating sea-wrack [sargazo], or others, I became persuaded that the two islands are in fact only one, with different longitudes and bore away to the South in pursuance of my commission.

On Sunday afternoon, the $25^{\text {th }}$ of the said [month], being in lat. $30^{\circ} \mathrm{S}$. and long. $261^{\circ} 36$, we caught sight of some white birds, which made me presume that land might be near: their flight at sundown was towards the South, Which was the course I was steering, and for this reason I shortened sail for the night with the object of seeing whether there might be any island in sight in the morning. Every care was taken as soon as the day broke, but nothing was seen ; and I proceeded in accordance with the orders in my sailing instructions, bearing the matter in mind with the intention of prosecuting the search farther before finally completing my commission.

On Thursday the $29^{\text {th }}$ of the same at seven in the evening, considering myself in lat. $38^{\circ} 30^{\prime} \mathrm{S}$. and long. 263'. I headed E., corrected, in compliance with the instructions. The wind is from N.N.W. to W., fresh, with a heavy sea from the S.W. From this position, day and hour, until Thursday the $6^{\text {th }}$ of December, the winds have been from N.N.W. to W.S.W., stronger each day, with continued squalls and stormy weather, and high seas I have kept my course at E. all the time, lying to under the main course every day after sundown and the special lookout, which is also attended to on resuming our way. On the latter day, considering myself in lat. $38^{\circ} 35^{\prime} \mathrm{S}$. and long. $279^{\circ}$, I gave the order at six in the evening to alter the course to E.S.E. magnetic, with the intention of making the port of San Carlos in the island of Chiloe. I did this because while following down the parallel of $38^{\circ} 30^{\prime}$, all the way from long. $263^{\circ}$ to long. $279^{\circ}$, I had seen no land nor even any of those signs, of which there are many, to indicate its proximity, and also in accordance with the instructions given me by the Most Excellent the Viceroy, and the resolution of the council I held for the purpose on the $14^{\text {th }}$ of November.

From the $6^{\text {th }}$ of December until the $9^{\text {th }}$ of the same, the winds have been very light, from the S., S.E., N.E., and N.N.W.; the sea from S.W. lumpy. On this $9^{\text {th }}$ I observed the sun in lat. $39^{\circ} 41^{\prime}$, and considered myself in long. $282^{\circ}$.

From noon of the $9^{\text {th }}$ of December until the $13^{\text {th }}$ of the same, the winds have been W.N.W. to W.S.W., very strong, with very rough sea. At four o'clock in the morning of this day I hove to sound, because the colour of the water looked as if it might be shoaling: and we did so with the satisfaction of knowing that we were within two leagues of the coast but we got no bottom at 250 fathoms, and I am sure that there is none in the position quoted, and that all we saw was a discolouration of the water. At twelve this day I observed the sun in lat. $41^{\circ} 40^{\prime} \mathrm{S}$., and considered myself in long. $296^{\circ} 35^{\prime}$

From the 13th of December to the 14th of the same, Friday, the winds were from W. to S.S.W., more moderate, the sea less rough, the horizon very obscure, with a thick haze. The water still retains its shoal like hue. I got no observation to-day and reckon myself in lat. $41^{\circ} 40^{\prime} \mathrm{S}$., and long. $299^{\circ} 56^{\prime}$ the entrance into Chiloe bearing E., distant 28 leagues.

From the $14^{\text {th }}$ of December until Saturday the $15^{\text {th }}$, at noon on that day, I continued under fore-course, topsails, and main topgallant-sail, heading E.: the wind moderate from W.S.W., a swell from the S.W.; there was a thick mist all day, so that the horizon could not be seen. The water presented by its colour an increasing appearance of shoaling on account of which, and because I had no hope of clearing up, I signalled the frigate at four o'clock to come within hail and I lowered the fore and main topsail yards on to the caps and lay awaiting her; and during interval we took reefs in the topsails. At six o'clock the frigate came up with us, and I hailed her to know what she reckoned her position as from the entrance to Chiloe. They replied that at noon they believed themselves to due West from it, 18 leagues distant. I told them to take a cast of the lead, and that I would do the same, which was thereupon done and we got bottom at 75 fathoms black sand, somewhat muddy. After this, at six o'clock we made sail with the fore and main courses and topsails, heading N.N.W., wind W. moderate, and at this time the frigate made the signal of land in sight, and we saw it well about three leagues away to the S.E.

From that time until three in the morning we continued making short boards within sight of the land and at the 
said hour we shook the reefs out of the topsails and got all plain sail set, making for the port with a moderate breeze from W.N.W. At ten o'clock we anchored in 12 fathoms, fine black sand, furled all the sails, and lowered the boats into the water; at twelve a kedge was laid out, and I ordered away a boat with an official letter to the governor. I occupied all this day and the 16th in warping up to the mooring ground, where I succeeded in arriving at ten o'clock on the morning of the 17 th.

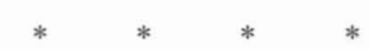

Orders issued by Commodore Don Felipe Gonzalez to officers of the San Lorenzo and Santa Rosalia, on their arrival at Easter Island:

[No. 1.] Señor Lieutenant don Alberto de Olaondo, and Ensign $\mathrm{D}^{\mathrm{n}}$ Juan de Hervé, also navigating officer of the first class, will embark in this ship's boat, together with the frigate's, which is to follow her, in charge of don Buenaventura Moreno, each furnished with marines under arms; they will take soundings of the whole of this bay as far as the shore, reconnoitre it thoroughly and its marks and bearings, record the depth of water in various positions, and the nature of the bottom, in order that the two vessels may let go their anchors where best calculated to ensure the most secure berth for them to lie in. $S^{n}$ Lorenzo, Under way: 15 th of November 1770 .

Don Phelipe Gonzalez.

[REPORT.] Having sounded over the whole of the bay as instructed by the foregoing order I found the bottom best adapted for the ship and the frigate to anchor on to lie N. and S. with it, about a mile and a half off shore, having 36 fathoms water, white sand and small gravel, protected also from the prevailing wind and sea from the S.E. Although there is less [swell] somewhat farther in, the water shoals rapidly to 25 fathoms, and the bottom is somewhat stony.

$S^{n}$ Lorenzo, dated as above. Alberto de Olaondo.

[No. 2.] Senior Lieutenant Du Cayetano de Langara, Ensign $\mathrm{D}^{\mathrm{n}}$ Juan de Hervé, and Passed Midshipman $\mathrm{D}^{\mathrm{n}}$ Pedro de Obregon, will embark in the launch in company with the frigate's, which will proceed in charge of don Emeterio Eseta, of similar rank, mounted with swivel guns, and carrying marines; they will proceed all round this island, prepare a plan of it, and examine all its harbours, bays, and creeks with the greatest care, ascertaining what depth of water there is in them, what the bottom is like, and everything worthy of notice and which may contribute to furnish a fully detailed [report or description of it]. For which purpose they will take sufficient provisions for as long as may be necessary for the execution of this commission, during which due regard will be had time in order that we may not be kept here longer than need be. Sn Lorenzo, $16^{\text {th }}$ of November, 1770 .

Don Phelipe Gonzalez.

[REPORT.] Plan enclosed ${ }^{3}$. Cayetano de Lángara.

[No. 3.] Señor Lieutenant $D^{n}$ Alberto de Olaondo, $D^{n}$ Vicente Eseta, of similar rank, Junior Lieutenant $\mathrm{D}^{\mathrm{n}}$ Antonio de Cordova, $\mathrm{D}^{\mathrm{n}}$ Jacobo Palavichini, $\mathrm{D}^{\mathrm{n}}$ Pedro and $\mathrm{D}^{\mathrm{n}}$ Rafael Guerrero de Torres, Lieutenant of Marines $\mathrm{D}^{\mathrm{n}}$ Juan Manterola, and $\mathrm{D}^{\mathrm{n}}$ Angel Garcia, Sub-lieutenant $\mathrm{D}^{\mathrm{n}}$ Gavino de San Pedro, Passed Midshipman $\mathrm{D}^{\mathrm{n}}$ Josef de Aramburu, and chief rigger ${ }^{4} \mathrm{D}^{\mathrm{n}}$ Luis Perez, will make ready to march at daybreak to-morrow the $20^{\text {th }}$ inst., and will land at the bay on the S.W. side of the island with 250 men, 125 being marines, and the rest seamen instructed in musketry, with which arm they will go provided. All will be under the orders of the said $\mathrm{D}^{\mathrm{n}}$ Alberto Olaondo, to whom I give full and very special power to see that from the moment they set foot on shore no one is to leave the ranks. Each one concerned in forming up the column will, on proceeding inland, keep to the best and most convenient order of march, so that they may not become fatigued and that no person shall stray apart; and if nevertheless anyone shall attempt to do so or to desert or otherwise offend while on the route by which they will travel they will be visited with punishment in proportion to the nature of their offence.

[The party] will enter into relations with the natives and get knowledge of the country and of its produce; and take bearings from some height in order to determine its extent, in furtherance of the examination made of its outline by the small boats of the ship and the frigate; using at the same time means to occupy the attention of the natives and draw them off from hindering by their numbers of the operation of erecting three crosses which is to be undertaken on the same day at the eastern side, on three hillocks which stand out near the point there. Possession of the island will be taken in the name of Our Catholic Monarch, and it is to be named in future the 'Island of San Carlos.'

On these orders being given effect to [the party] will return to the same place where it disembarked, in order to be conveyed on board, arranging the time in such a manner that they get back early enough for those who go to the ceremony of the Proclamation and erection [of the crosses] to return, on its completion, and avoid the confusion attending a re-embarkation after nightfall.

\section{$S^{n}$ Lorenzo, $19^{\text {th }}$ of November 1770. $\mathrm{D}^{\mathrm{n}}$ Phelipe Gonzalez.}

[REPORT.] In compliance with the instructions issued to me in the foregoing order I have given effect to them in the following manner. At half-past four in the morning I landed [my party] at the south-western side of the island, in

\footnotetext{
${ }^{3}$ Here occurs the plan of the Isla de San Carlos; there is no verbal report with it, but the narrative of the launches' circumnavigation is contained in that written by Lieut. Hervé.

4 'boatswain' - maestro de Jarcia in the MS.
} 
Rapa Nui Journal: Journal of the Easter Island Foundation, Vol. 21 [2007], Iss. 2, Art. 9

consequence of which unusual sight a number of the natives presented themselves and lent assistance, and accompanied us after we had formed into a column of eight companies, each one with its allotted officers and people. I directed my march towards the top of an eminence which might be from two to two and a half leagues distant, where I only arrived at eight o'clock in the morning, having had to mount up several times on the way in consequences of the undulations in the ground being so bad that I found it necessary to quit the formation in which we were proceeding and to follow the footpath in single file. We then arrived at the last hill, which commanded [a view of] the whole island, and I saw that its greatest extent runs from N.E. to S.W. five and a half or six leagues, and the least about N. and S. four and a half to five leagues. At this central point we now halted. Its circumference may be from twelve to fourteen leagues, and its configuration may be from twelve to fourteen leagues, and its configuration as shown on the plan. Having made overtures to the natives I found them to be entirely docile and very timorous, for the reason that they have never held intercourse with any people save each other; thus, although they did not venture to approach to where we were standing, the seemly and civil manner in which they kept aside at the landing-place, and the same behavior in everything at our going, and while there, and when under sail on our way back to the ship, the salute announcing the conclusion of our ceremony, and the readiness of those taking part in it to withdraw for re-embarkation, allowed me time and daylight enough to carry out that portion of the foregoing order which relates thereto. $S^{n}$ Lorenzo, dated as above. Alberto de Olaondo.

[Official InStruction.] Señor $\mathrm{D}^{\mathrm{N}}$ Josef Busdtillos. Having decided to take possession on the morning of the 20th inst. of this island lately discovered by us, in the name of our Catholic Monarch after whom it is to be called the 'Island of San Carlos', you will hold yourself in readiness to proceed ashore in this ship's boat in order to direct and bear witness to the ceremony; for which purpose the detachment commanded by $\mathrm{D}^{\mathrm{n}}$ Buenaventura Moreno, Captain of Marines, and the following officers are appointed $-\mathrm{D}^{\mathrm{n}}$ Juan de Landecho, $\mathrm{D}^{\mathrm{n}}$ Josef Serrato, $\mathrm{D}^{\mathrm{n}}$ Juan Nepomuceno
Morales, $\mathrm{D}^{\mathrm{n}}$ Francisco de Aguera, Passed Midshipmen $\mathrm{D}^{\mathrm{n}}$ Josef Morales and $\mathrm{D}^{\mathrm{n}}$ Pedro de Obregon, Staff Paymasters $\mathrm{D}^{\mathrm{n}}$ Antonio Romero and $\mathrm{D}^{\mathrm{n}}$ Pedro Freyre de Andrade, Boatswain $\mathrm{D}^{\mathrm{n}}$ Josef Antonio Areales, and the Chaplains $\mathrm{D}^{\mathrm{n}}$ Felix Camuñez and $\mathrm{D}^{\mathrm{n}}$ Francisco de Guebara, together with an armed party of seamen to form a guard in conjunction with the aforesaid detachment in order that the function may be invested with due formality.

You should conduct the ceremony on the hill situated near-by the N.E. point of the island, and cause a cross to be planted on each of the three hillocks which crown its summit and extend in line with the point. This should be done simultaneously on each, and after reading the Proclamation you will give order for a triple salute to be fired by the musketry party, and seven cheers of 'Long live the King!' The ship and frigate will respond with 21 guns; and you will cause the Paymasters to furnish you with a declaration of all that is done, to which you will procure the attestations of the recognized Chiefs or Caciques of the islanders, signed in their native characters ${ }^{5}$ in testimony of the satisfaction and general acquiescence with which they have all agreed to and acknowledge the cession. These instructions being given effect to, you will get the launches and boats ready, that all the people may be embarked for return to their respective ships.

$$
\begin{array}{r}
S^{n} \text { Lorenzo, 19th of November, } 1770 . \\
\text { Phelipe Gonzalez }
\end{array}
$$

[DECLARATION.] The following attestation is made in obedience to the foregoing Official Instruction.

$\mathrm{D}^{\mathrm{n}}$ Antonio Romero, Staff Paymaster in the Royal Navy, at present serving on board H.M. Ship of the Line named the $S^{n}$ Lorenzo.

I certify - that, by direction of $\mathrm{D}^{\mathrm{n}}$ Felipe Gonzalez y Haedo, Captain in the Royal Navy, commanding this ship and the Frigate $S^{n}$ Rosalia sailing under her escort, when the Most Excellent Señor the Viceroy, Governor, and CaptainGeneral of the Kingdom of Peru, $D^{n}$ Manuel de Amat, under whose orders he is, has appointed for the investigation of this island, commonly marked on the charts by the name of David, it has been on the day and date hereof been exam-

${ }^{5}$ On the 9th of December 1873 a deeply interesting communication was made to the members of the Anthropological Institute of Great Britain and Ireland, by J. Park Harrison, Esq. M.A. on "The Hieroglyphic of Easter Island." The paper read had reference to the kyriographic characters of ancient date graven by means of obsidian tools upon wooden tablets, which had been revealed to the missionary Eugène Eyraud, a lay brother of the congregation of the Sacred Heart of Picpus, about the year 1864. Much more concerning these tablets, and others of the same kind which have since come to light, has been discovered and studied of late years; and various workers claim, with more or less plausibility, to have deciphered these curious inscriptions. After Mr Harrison's paper was concluded Señor Gonzalez de la Rosa, a member of the Anthropological Institute and of the Royal Geographical Society of London, exhibited to the meeting a MS. containing some account of expeditions made to the Pacific Islands by order of the Viceroy of Peru, from 1770 to 1774, the last eight pages of which related to Easter Island, and the voyage of Don Phelipe Gonzalez, with the ships San Lorenzo and Santa Rosalia.

"On the 15th of November," said the MS., "they took possession of the island on behalf of his Catholic Majesty Don Carlos III ; and for that reason they gave to the island the name of San Carlos, instead of David as it was previously called. On that occasion, after the deed of possession had been signed by all of the expeditioners, they invited the caciques to do the same, as an act of donation to the King of Spain. Then the chiefs drew the characters contained in the MS., the correctness and authenticity of which is testified by $\mathrm{S}^{r}$ Antonio Romero, the secretary of the expedition." The characters are reproduced in this volume. 
ined by sea and by land, and there has in so far as is possible been made known to and recognized by its native inhabitants their lawful Sovereign, and his powerful arm for their defence against foreign enemies, this which they have acknowledged with many demonstrations of pleasure and

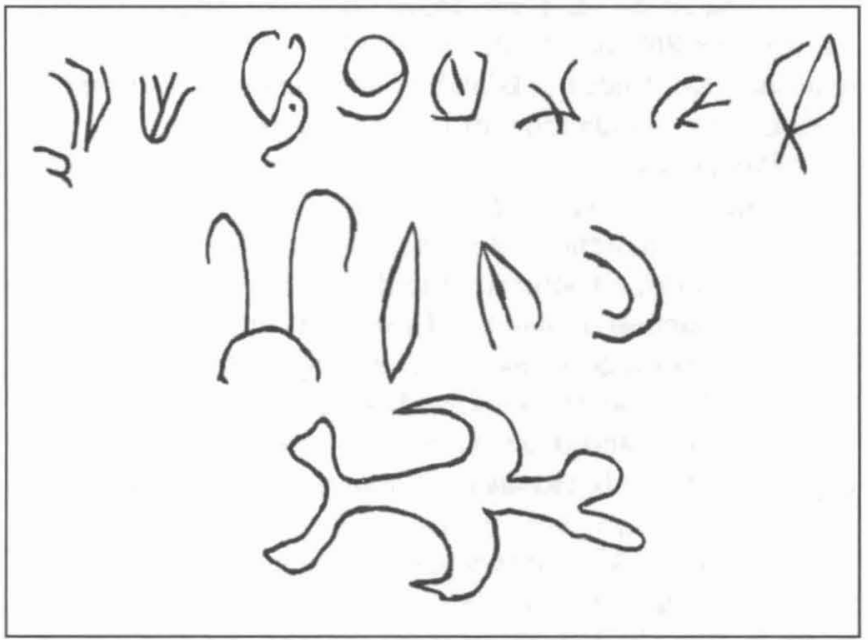

Signatures of the chiefs of Easter Island on the Spanish treaty, 1770.

rejoicing. And in testimony of so happy a success three crosses have, by their consent, been erected on the hill which is at the N.E. extremity of the island; and the name of $S^{n}$ Carlos has been bestowed upon the said island, in the presence of the native inhabitants assembled to the number of 800 , and of all the officers, crew, and ship's company told off for the occasion under the command of $\mathrm{D}^{\mathrm{n}}$ Josef Bustillos, Knight of the Order of $\mathrm{S}^{\mathrm{t}}$ James and a Commander in the Royal Navy. And the three crosses being set up in position, the litany was sang; and at its conclusion a triple salute of musketry was fired by the aforesaid seamen and the ship's company, and another of 21 guns by the ship and the Frigate.

And in order that this act of solemn possession may be made known and established by evidence, I declare this at the Island of $S^{n}$ Carlos: the $20^{\text {th }}$ of November, 1770.

$\mathrm{D}^{\mathrm{n}}$ Antonio Romero.

\section{JOURNAL OF THE PRINCIPAL OCCURRENCES DURING THE VOYAGE OF THE FRIGATE $S$ ANTA Rosalia from El Callao de lima to the ISLAND OF DAVID AND THENCE TO SAN CARLOS DE CHILOE, IN THE YEAR 1770. BY AN OFFICER OF THE SAID FRIGATE ${ }^{12}$}

Journal of the principal occurrences during the voyage of the Frigate Santa Rosalia, under the command of Captain Don Antonio Domonte, which sailed from the Port of the Callao on the $10^{\text {th }}$ of October, 1770 , in company with the ship of the line San Lorenzo, Commodore don Felipe González; to find and examine the Island of David, and others in the South Seas, her chief pilot being don Francisco Antonio de Agüera Infanzon. ${ }^{6}$

On Wednesday, the $10^{\text {th }}$ of October, 1770, at half-past four o'clock in the afternoon, we put to sea with a fresh breeze from S.S.E., making all sail in order to join company with the Commodore, which we succeeded in doing at sundown: the north-western headland of the island of San Lorenzo of the Callao bearing then S., $5^{\circ}$ S.E., distant $3 / 4$ of a league, and at eight o'clock from $2 \frac{1}{2}$ to 3 leagues off on the same bearing.

From this point I took my departure, fixing as my base the latitude of $12^{\circ} 5^{\prime}$, land longitude $298^{\circ} 45^{\prime}$, meridian of Tenerife. We set our course to the S.W. with the wind fresh from S.S.E.

Thursday, $11^{\text {th }}$. I could get no observation at noon: by my reckoning I was in lat. $12^{\circ} 29^{\prime}$ and long. $297^{\circ} 45^{\prime}$. Course $68^{\circ}, 3^{\text {rd }}$ quadrant. Distance $631 / 2$ miles. The winds were fresh, from the $2^{\text {nd }}$ quadrant. ${ }^{14}$

Friday, $12^{\text {th }}$. At noon I observed the sun in lat. $13^{\circ} 1$ '. Course $60^{\circ} 15^{\prime}, 3^{\text {rd }}$ quadrant. Distance 65 miles. Longitude reached $296^{\circ} 46^{\prime}$ : the same wind continued.

Saturday, $13^{\text {th }}$. Latitude by observation $13^{\circ} 37^{\prime}$, long. $295^{\circ} 25^{\prime}$. Courses $65^{\circ} 30^{\prime}, 3^{\text {rd }}$ quadrant. Distance 87 miles.

Sunday, $14^{\text {th }}$. Lat. by observation $14^{\circ} 40^{\prime}$, long. $293^{\circ}$ $20^{\prime}$. Course $56^{\circ} 30^{\prime}, 3^{\text {rd }}$ quadrant. Distance 115 miles. Wind $2^{\text {nd }}$ quadrant.

Monday, $15^{\text {th }}$. Lat. by reckoning $16^{\circ} 6^{\prime}$, long. $292^{\circ} 32^{\prime}$. Course $45^{\circ} 15^{\prime}, 3^{\text {rd }}$ quadrant. Distance 118 miles. Wind $2^{\text {nd }}$ quadrant, fresh.

Tuesday, $16^{\text {th }}$. Lat. by observation $17^{\circ} 27^{\prime}$, long. $231^{\circ}$ $32^{\prime}$. Course $32^{\circ}, 3^{\text {rd }}$ quadrant. Distance 96 miles: wind ...... idem.

Wednesday, $17^{\text {th }}$. Lat. by observation $18^{\circ} 37^{\prime}$, long. $290^{\circ} 46^{\prime}$. Course $33^{\circ} 30^{\prime}, 3^{\text {rd }}$ quadrant. Distance $801 / 2$ miles: wind .... idem.

\footnotetext{
${ }^{6}$ Probably Don Francisco Antonio de Agüera y Infanzón, Chief Pilot.

${ }^{7}$ Two officially attested copies of the original of this Journal exist in the library of the Real Academia de la História at Madrid, both made by royal Command in 1778. The original itself was deposited in the Archives of the Dispacho Universal de Indias - the colonial Office of Spain. There is also a copy, on paper and in handwriting of the same period, in the British Museum.

${ }^{8}$ A quadrant refers to a geographic subdivision of a zone, region, or area rendered cartographically to establish position in concert with other measurements; e.g., latitude, longitude and distance. Apparently whatever measurement that provided latitude, longitude, course, and distance traveled also included the quadrant where the previous three measurements were taken and is therefore was one part of a series of indicators showing location.
} 